\title{
Direitos e cidadania no Rio de Janeiro: poder e disputas por espaços de trabalho na praia da Saúde em 1841
}

\section{Edilson Nunes dos Santos Junior*}

Resumo: A relação entre cidadania e trabalho está diretamente associada à reivindicação de direitos no Rio de Janeiro oitocentista. Conflitos entre instituições responsáveis pela regulação e controle dos mundos do trabalho abriram possibilidades à conformação de estratégias populares de luta por espaços de trabalho e condições de sobrevivência. A representação dos moradores da praia da Saúde em 1841 permite analisar como os cidadãos da corte entenderam e utilizaram os dispositivos legais e as sobreposições de jurisdição entre a Câmara Municipal e o Juízo de Paz em defesa de seus espaços de trabalho como exercício da cidadania..

Palavras-chave: Barqueiros; Câmara Municipal; Juiz de Paz.

Abstract: The relationship between citizenship and labor is directly related to clamming rights in 19th Rio de Janeiro. The conflicts among institutions responsible for regulation and control of the worlds of labor opened ways for popular strategies of struggle to labor and survival conditions. The inhabitants' representation in praia da Saúde in 1841 allows to investigate how citizens perceived and used legal norms and jurisdictional conflicts between City Council and Justice of the Peace in defense their labor locations like practice of citizenship.

Keywords: Boatmen; City Hall; Justice of the Peace.

\section{Introdução: mundos do trabalho e da cidadania carioca}

Nos últimos vinte anos, as pesquisas sobre os mundos do trabalho na cidade do Rio de Janeiro no século XIX têm privilegiado a análise da documentação produzida pela municipalidade para investigar as ações dos trabalhadores e as leituras que eles fizeram sobre o controle exercido pelas autoridades públicas. Através da investigação da relação deles com a Câmara Municipal e desta com

* Doutorando pelo Programa de Pós-Graduação em História Social da Universidade Federal Fluminense, mestre e especialista em História do Rio de Janeiro pela mesma instituição. Bolsista CAPES. E-mail: diljunior5@gmail.com. 
outros agentes públicos é possível percorrer as disputas pelo exercício de diversos ofícios, as relações de trabalho entre diferentes condições jurídicas e, ainda, perceber o controle do Estado sobre a regularização e a normatização do trabalho num período bastante anterior ao estabelecimento de leis trabalhistas.

A documentação da municipalidade tem proporcionado deslindar as relações sociais de agentes históricos por outras perspectivas e por métodos diferentes que dão aos mundos do trabalho uma nova dinâmica. A presença de imigrantes europeus e africanos livres e libertos também tem sido analisada e tem indicado novos caminhos na percepção e no entendimento de um mercado de trabalho muito disputado. Pioneiramente, Gladys Sabina Ribeiro indicou uma hierarquização nos postos de trabalho no Rio de Janeiro. ${ }^{1}$ De maneira geral, os portugueses ocuparam postos de comando ou executaram trabalhos que demandavam maior responsabilidade, sem obedecer a uma rigidez muito definida, dentro da lógica de valorização do trabalho do homem branco e a elevação a conceitos negativos da imagem do negro enquanto trabalhador. ${ }^{2}$

Desde então, muito tem-se buscado para investigar as ações populares no oitocentos de forma que as experiências dos trabalhadores e dos cidadãos da cidade do Rio de Janeiro têm ganhado uma forte complexidade. Reivindicações dos caixeiros, ${ }^{3}$ dos trabalhadores de quiosques da cidade, ${ }^{4}$ dos trabalhadores marítimos que atuavam no litoral da Corte, ${ }^{5}$ dos carregadores e carroceiros, ${ }^{6}$ ou das africanas e dos africanos que atuavam no Mercado do Peixe, ${ }^{7}$ foram pesquisas que aprofundaram as diferentes categorias de trabalhadores e as diversas relações de classe e de trabalho a partir da sua relação com a Municipalidade. ${ }^{8}$

Ainda assim, podemos acrescentar novos fatores na reflexão sobre a construção de uma cidadania oitocentista no Rio de Janeiro e a sua ligação intrínseca com as relações de classe e de trabalho. Nesse sentido, este artigo busca um diálogo entre a História Política e a História Social do Trabalho de modo a dar um novo significado e uma maior complexidade às diversas dimensões que exerceram influência e foram influenciadas pelos mundos do trabalho. As relações

1 RIBEIRO, Gladys Sabina. A liberdade em construção: identidade nacional e conflitos antilusitanos no primeiro reinado. Rio de Janeiro: Relume Dumará/FAPERJ, 2002.

2 RIBEIRO. A liberdade em construção, p. 207.

3 POPINIGIS, Fabiane. "Operários de casaca? Relações de trabalho e lazer no comércio carioca na virada dos Séculos XIX e XX”. (Tese de Doutorado em História, Unicamp, 2003).

4 SOUZA, Juliana Teixeira. "A autoridade municipal na Corte imperial: enfrentamentos e negociações na regulação do comércio de gêneros (1840-1889)”. (Tese de Doutorado em História, Unicamp, 2007).

5 SANTOS JUNIOR, Edilson Nunes dos. "Sobre as águas da Guanabara: transporte e trabalho no Rio de Janeiro do século XIX (1835-1845)". (Dissertação de Mestrado em História, Universidade Federal Fluminense, 2016).

6 TERRA, Paulo Cruz. Cidadania e Trabalhadores: cocheiros e carroceiros no Rio de Janeiro (1870-1906). Rio de Janeiro: Prefeitura do Rio/Casa Civil/Arquivo Geral da Cidade do Rio de Janeiro, 2013.

7 FARIAS, Juliana Barreto. "Mercados minas: Africanos ocidentais na Praça do Mercado do Rio de Janeiro,1830-189o". (Tese de Doutorado em História, Universidade de São Paulo, 2012).

8 Sobre outros trabalhos que tiveram os documentos municipais como fonte de investigação, ver ente outros: GOMES, Flávio dos Santos; SOARES, Carlos E. Líbano. "Dizem as quitandeiras": ocupações urbanas e identidades étnicas numa cidade escravista: Rio de Janeiro, século XIX”. Acervo, Rio de Janeiro, v.15, n.2, pp. 3-16, jul./dez.2002; Disponível em: http://revista.arquivonacional.gov.br/index.php/revistaacervo/article/ view/211/211. Acessado em: 12/09/2017; KARASCH, Mary C. A vida dos escravos no Rio de Janeiro (1808-1850). Tradução: Pedro Maria Soares. São Paulo: Companhia das Letras, 2000; MATTOS, Marcelo Badaró. Escravizados e livres: experiências comuns na formação da classe trabalhadora carioca. Rio de Janeiro: Bom Texto, 2008; GOLDMACHER, Marcela; MATTOS, Marcelo Badaró; TERRA, Paulo Cruz (Orgs.). Faces do Trabalho: escravizados e livres. Niterói: EdUFF, 2010; SOARES, Luiz Carlos Soares. O "Povo da Cam" na Capital do Brasil: a escravidão urbana no Rio de Janeiro do século XIX. Rio de Janeiro: Faperj/7Letras, 2007; SOARES, Mariza de Carvalho; BEZERRA, Nielson Rosa. (orgs.). Escravidão africana no Recôncavo da Guanabara (séculos XIII-XIX). Niterói: EdUFF, 2011; TERRA, Paulo Cruz. "Tudo que transporta e carrega é negro? Carregadores, cocheiros e carroceiros no Rio de Janeiro (1824-1870)”. (Dissertação de Mestrado em História, Universidade Federal Fluminense, 2007). 
sociais, políticas, econômicas e culturais são inter-relacionais e multifacetadas e as personagens envolvidas ganham profundidade ao se explorar as suas ações em espaços políticos diversos. Essa atuação, aqui representada pela busca por direitos considerados justos ou costumeiros é atravessada, necessariamente, por uma ação política através dos novos instrumentos disponíveis com o constitucionalismo da primeira metade do século XIX brasileiro.

No Rio de Janeiro oitocentista, a luta pelo que se consideravam(?) direitos passou necessariamente pelas relações de trabalho em uma cidade que crescia constantemente em números de habitantes e nos limites espaciais. Defender direitos costumeiros significava defender direitos à posse da terra, ao uso do espaço urbano, à liberdade de circulação e à uma condição mínima de sobrevivência e de trabalho. E falar em direitos costumeiros, em reivindicação do que se achava direito pelo uso e ocupação tradicional no Brasil do século XIX é ter em perspectiva a herança de Antigo Regime presente em todos os níveis da sociedade. As petições e/ou requerimentos junto às diversas instituições imperiais foram instrumentos poderosos de reivindicação e um exemplo dessa forma de se relacionar e de se apropriar dos dispositivos legais. Instrumentos esses que vinham sendo resignificados e utilizados de novas maneiras que não correspondiam, na maioria das vezes, ao projeto original dos seus formuladores.

Como veremos neste artigo, através das petições dos moradores da praia da Saúde, que se consideravam prejudicados pela presença das embarcações de comerciantes da praça do Rio de Janeiro, é possível rastrear a leitura que os cidadãos da cidade faziam dos códigos e das posturas e como percebiam as diferenças de atuação das instituições imperiais encarregadas da observação da legislação em vigor. De outro lado, veremos como o acionamento ao argumento da ancestralidade do uso do espaço atravessado pela questão econômica dos comerciantes demonstram a ressignificação da forma e do conteúdo na relação com o Estado no cotidiano oitocentista.

\section{Espera Receber Mercê. Ou justiça? A cidadania através do exercício peticionário}

As petições e/ou requerimentos junto às instituições municipais e imperiais faziam parte de um processo político que teve sua gênese na emancipação política brasileira e estava ligado ao descolamento da herança colonial. Houve a necessidade de elaboração de um corpo legislativo que representasse a nova nação em construção. ${ }^{9}$ Segundo Vantuil Pereira, analisando a inserção política e a busca por cidadania através dos requerimentos apresentados ao Parlamento pela população no Primeiro Reinado, o ato de peticionar remonta, antes, a uma herança do mundo ibérico do século XVII. As petições serviam como um instrumento dos súditos diante de situações diversas, mas, principalmente, para legitimar o poder real.

9 Sobre o assunto, ver, principalmente: IAMASHITA, Léa. M. Carrer. "A Câmara Municipal como instituição de controle social: o confronto em torno das esferas pública e privada". Revista do Arquivo Geral da Cidade do Rio de Janeiro, Rio de Janeiro, v. 3, p. 41-56, 2009. Disponível em: http://wwwo.rio.rj.gov.br/arquivo/ pdf/revista_agcrj_pdf/revista_agcrj_3.pdf. Acessado em: 12/09/2017; PEREIRA, Vantuil. "Ao Soberano Congresso": Petições, Requerimentos, Representações e Queixas à Câmara dos Deputados e ao Senado - Os direitos do cidadão na formação do Estado Imperial brasileiro (1822-1831)". (Tese de Doutorado em História, Universidade Federal Fluminense, 2008). 
Diante deste mecanismo, não só o súdito poderia reivindicar direitos diretamente ao rei, como também poderia denunciar atos excessivos cometidos pelas autoridades, pois muitas vezes acreditava-se que o soberano não tinha conhecimento do que os seus representantes faziam nas mais longínquas partes do Reino. ${ }^{10}$

Esse sentido transformou-se substancialmente a partir das revoluções ocorridas na França, na Inglaterra e nos Estados Unidos ao longo do século XVIII, nos quais as petições passaram a significar, e ter a função mesma, de reivindicação de direitos. Houve o distanciamento do sujeito peticionário, que passou a ser mais cidadão e menos súdito. Além disso, o endereçamento de tais petições não se restringia mais ao soberano, mas destinava-se às diversas esferas de poder estabelecidas pelas mudanças liberais. ${ }^{11}$

A expectativa do cidadão de poder interferir na vida política e cotidiana espraiou-se pelos mais diversos níveis sociais, gerando o desejo de participar, manifestar-se, reivindicar o que se achava justo, repreender o que se achava injusto ou arbitrário.

O mecanismo peticionário das primeiras duas décadas da Independência brasileira é constituído de ambiguidades, pois combinava valores do Antigo Regime e novos significados políticos. Corporificava as contradições da sociedade imperial brasileira. Constituía-se em uma nova prática política, relida a partir da própria tradição portuguesa. ${ }^{12}$

Estabelecida a emancipação política, a década de 1840 foi crucial para a estabilização do Império brasileiro com a resolução das diversas revoltas que convulsionaram o período regencial e com o rearranjo institucional que redefiniu e criou novas instituições. Segundo Roberto Saba, as petições foram um forte instrumento de participação cidadã neste processo e de diálogo com o Legislativo no início do Segundo Reinado. Analisando um grupo de petições enviadas à Câmara dos Deputados, Saba verificou uma ligação intrínseca entre Estado e sociedade civil consubstanciada no envio e na leitura das petições nas sessões legislativas. ${ }^{13}$ Para Elizabeth Sant'Anna, o discurso peticionário desvela a ação de cidadãos em busca do que entendem serem seus direitos, bem como seu posicionamento perante diferentes assuntos ou como uma estratégia de sobrevivência frente às transformações políticas e econômicas da década de $1850 .^{14}$

No meio militar, o uso de petições também foi um expediente muito explorado para a reivindicação de direitos e súplicas de socorro ou fuga do alistamento. Investigando os marinheiros e os recrutas da Armada Imperial na primeira metade do oitocentos, Silvana Jeha afirma que essas petições ou, no caso dos militares e familiares da Armada, requerimentos trazem uma retórica ocidental assentada em práticas de Antigo Regime, onde se expressavam a fé e a confiança na justiça do rei ${ }^{15}$.

10 PEREIRA. "Ao Soberano Congresso", p. 216.

11 PEREIRA. "Ao Soberano Congresso", p. 218-219.

12 PEREIRA. "Ao Soberano Congresso", p. 220.

13 SABA, R. "As Vozes da Nação: a atividade peticionária e a política do início do Segundo Reinado". (Dissertação de Mestrado em História, Universidade de São Paulo, USP, 2010), p. 7-8.

14 SANT’ANNA, E. A. M. F. "Súplicas a Vossa Majestade Imperial: as negociações em tempos de mudanças". In: RIBEIRO, Gladys Sabina; MARTINS, Ismênia de Lima; FERREIRA, Tânia Maria Tavares Bessone da Cruz (orgs.). O Oitocentos sob novas perspectivas. São Paulo: Alameda, 2014, p. 139-159.

15 JEHA, Silvana Cassab. "A galera heterogênea: naturalidade, trajetória e cultura dos recrutas e marinheiros da Armada Nacional e Imperial do Brasil, c. 1822 - c. 1854". (Tese de Doutorado em História, Pontifícia Universidade Católica do Rio, PUC-RIO, 2011). p. 175-177. 
O século XIX brasileiro foi um momento de ressignificação dos instrumentos de reivindicação de direitos. Se a forma das petições e dos requerimentos seguia a herança de Antigo Regime, o conteúdo vinha carregado de noções de direitos e de justiça próprias do liberalismo contemporâneo. Nesse sentido, Juliana Barreto de Souza defende que havia uma necessidade que ia além da submissão com o objetivo de reivindicar direitos costumeiros. ${ }^{16}$ Esse argumento se coaduna com outras pesquisas ao demonstrar que as noções de Antigo Regime vinham sendo resignificadas pelos cidadãos do Império. Para ela, os trabalhadores e os proprietários de quiosques do Rio de Janeiro estavam agindo dentro da lógica do mercado e do lucro, a partir de práticas econômicas que estavam a cada dia mais se expandindo e se consolidando nas bordas do Atlântico. A autora identificou o período de 1840 a 1889 como um momento de transformação das relações sociais, políticas e econômicas, que permitiu a essas personagens acionar diferentes instrumentos através de lógicas diversas na luta diária pelo exercício da cidadania e por espaços de trabalho. ${ }^{17}$

Portanto, o cidadão carioca, diante do acesso às novas formas de comunicação com as diversas e novas instituições políticas, tinha a percepção de que através do mecanismo da petição poderia intervir não só no jogo político, mas na defesa de interesses que avançavam e mudavam de maneira significativa os valores e as práticas cotidianas. O contexto de transformações do final do século XVIII e início do século XIX permitiu a mudança do conceito de política e de fazer política nas sociedades atlânticas. Por passar a ser tratada como um campo específico, possibilitou o surgimento do espaço público das discussões políticas:

Na sociedade das luzes, o ser cidadão do mundo se reportava às relações entre o indivíduo e a sociedade e entre o indivíduo e o rei. A participação era mais intensa e se exigiam direitos, o que levava a uma internalização da necessidade de cumprir obrigações diante do Estado e pari passu se cobrava o igual cumprimento de funções tais como proteção e salvaguarda da ordem. O indivíduo aprendia que os valores do poder público deveriam ser preservados e ele tinha um papel importante nisso. ${ }^{18}$

Esse processo de tomada de consciência política ou uma nova forma de se relacionar com as instituições políticas e delas com a população insere-se em contexto de profundas mudanças ocorridas durante o século XIX.

A modernização política, no que se refere ao desempenho do governo e do sistema na sua globalidade, ocorre quando se verifica um aumento da capacidade das autoridades em dirigir os negócios públicos, em controlar as tensões sociais e em enfrentar as exigências e atender às demandas da sociedade. No que se refere à população, ocorre modernização política quando se verifica na sociedade a passagem de uma condição generalizada de súditos para cidadãos, por uma maior sensibilidade e adesão aos princípios de igualdade, e por uma mais ampla aceitação do valor das leis. ${ }^{19}$

Ao longo do oitocentos, podemos verificar, no Rio de Janeiro, uma transformação profunda entre cidadania e trabalho materializada na reivindicação de direitos

16 SOUZA. "A autoridade municipal na Corte imperial".

17 SOUZA. "A autoridade municipal na Corte imperial”. Ver o quarto capítulo, p. 168-215.

18 RIBEIRO, G. S. "Nação e cidadania nos jornais cariocas da época da Independência: o Correio do Rio de Janeiro como estudo de caso". In: CARVALHO, José Murilo; NEVES, Lúcia Bastos Pereira das. (Org.). Repensando o Brasil do Oitocentos. Cidadania, política e liberdade. Rio de Janeiro: Civilização Brasileira, 2009, p. 216.

19 IAMASHITA. "A Câmara Municipal como instituição de controle social, p. 72. 
diversos através das petições ou requerimentos junto à Municipalidade ou às outras instituições imperiais. O caso apresentado a seguir demonstra como os cidadãos cariocas dominavam os recursos disponíveis e exploravam a concorrência de poderes produzida pela sobreposição de jurisdições entre a Câmara Municipal e o Juízo de Paz, que até 1841, tinha extensos poderes sobre o cotidiano da população. É perceptível a necessidade de se fazer ouvido e de externalizar as insatisfações tendo nos canais oficiais de comunicação - as petições - o instrumento viabilizador desse processo.

\title{
Sob o perigo de funestos crimes: direito ao espaço e ao trabalho na praia da Saúde
}

No dia 31 de março de 1841, Francisco Alves de Oliveira, Joaquim Moreira dos Santos, José Antônio Homem e outros dezessete representantes dos moradores da praia da Saúde peticionaram ao juiz de paz do Segundo Distrito da freguesia de Santa Rita sobre os incômodos causados pela presença de saveiros e outras embarcações miúdas que ali eram consertadas, limpas e fabricadas. Os moradores reclamavam do cheiro produzido pela queima de combustíveis necessários para essas atividades, afirmando que "homens, mulheres e crianças se veem obrigados a saírem de suas casas para procurarem um ar para respirar a afim de não serem sufocados pelo fumo, sendo digno da piedade ver as crianças quase sufocadas, procurarem suas mães para as socorrerem". Além disso, acrescentavam o barulho insuportável causado pelos calafates e seus instrumentos. ${ }^{20}$

Os moradores pediam que acabassem os transtornos que vinham ocorrendo no logradouro entre as ruas do Cemitério e do Propósito. Destacaram, em sua representação, o caráter público do espaço, sendo a praia utilizada para o embarque e desembarque da população em geral, e todo o incômodo que a presença e ação daquelas embarcações e dos seus remadores causariam ao trânsito dos cidadãos e que tal situação afrontava diretamente as posturas municipais no que diz respeito à Seção $2^{\text {a }}$, Título $3^{\circ}$, Parágrafo $4^{\circ}$ do Código de Posturas Municipais:

Éabsolutamenteproibidodepositarnasruas dacidade, suas praças, cais,e outros lugares públicos de seu termo, qualquer objeto, ainda mesmo que este depósito seja momentâneo. O infrator incorrerá na multa de $10 \$ 000$ réispelaprimeiravez;e, nasreincidências,em30\$000 réise8diasdecadeia.

\begin{abstract}
Éabsolutamenteproibido depositarnasruas dacidade, suas praças, cais, e outros lugares públicos de seu termo, qualquer objeto, ainda mesmo que este depósito seja momentâneo. O infrator incorrerá na multa de $10 \$ 000$ réispelaprimeiravez;e, nasreincidências,em30\$000 réise8diasdecadeia.

O fiscal deverá conduzir para o depósito público os objetos encontrados nos lugares mencionados, os quais não serão entregues ao possuidor sem que este se mostre quite com o tesoureiro da Câmara Municipal, tanto na multa como na despesa que se fizer com a remoção dos ditos objetos, sem que possa pedir indenização pelo prejuízo que houver. ${ }^{21}$
\end{abstract}

20 Arquivo Geral da Cidade do Rio de Janeiro (AGCRJ). Série Embarcações: Códice 57.3.11 (1813-1903) - Vários documentos acerca do tráfego, pesca e venda de mercadorias: Certidão de inteiro o teor de um requerimento que me foi dirigido pelos moradores em frente do logradouro público que existe entre as ruas do Cemitério e do Propósito, bem como o teor do meu despacho proferido nesse requerimento, p. 52-54; 56-58.

21 Código de Posturas da llustríssima Câmara Municipal do Rio de Janeiro e Editais da mesma Câmara, 1838. 
Mas os moradores não se restringiram às posturas municipais ao denunciar as relatadas transgressões dos trabalhadores que atuavam naquele logradouro público. Evocaram o Código de Processo Criminal, no seu artigo 206, que previa ao juiz de paz formar um ato a partir do conhecimento de infração das posturas, com declaração de testemunhas e citação do infrator na forma do artigo antecedente, que determinava:

Art. 205. Apresentada ao Juiz de Paz uma denúncia de contravenção às posturas das Câmaras Municipais, ou queixa de crime, cujo conhecimento, e decisão final lhe compete, mandará citar o delinquente para a sua primeira audiência (que nunca será a do mesmo dia da citação).

E reconheciam naquele momento (março de 1841), que cabia ao juiz de paz "proceder contra os infratores das posturas municipais, impondo as penas das mesmas posturas". ${ }^{22}$

Emseu despacho, o juiz de paz Gabriel Pinto de Almeida, muito diligentemente, acatou todas as reclamações dos moradores e determinou que o escrivão do distrito mandasse publicar edital decretando a prisão em flagrante daqueles que fossem surpreendidos na continuidade do delito após a ciência das determinações do juiz e intimando aqueles que mantivessem depositados no dito logradouro objetos diversos, com prazo de três dias para a retirada dos mesmos, além do processo na forma da lei. O edital foi publicado no Diário do Rio de Janeiro em $1^{\circ}$ de abril daquele ano, assim determinando:

\begin{abstract}
Gabriel Pinto de Almeida, Juiz de Paz do Segundo Distrito da Freguesia de Santa Rita, faço saber às pessoas que costumam embaraçar com seus saveiros e outras embarcações desta natureza o logradouro público que fica entre as ruas do Cemitério e Propósito; assim como encalharem, fabricarem, e consertarem as mesmas embarcações no dito lugar, com manifesta infração das posturas da Câmara Municipal, título terceiro, parágrafo quarto, sessão segunda, que não poderão de hoje em diante continuar em semelhante procedimento, que thes é proibido, acrescendo a isto uma representação que me dirigiram os moradores do dito lugar, em que se queixam do grave incômodo e vexame em que vivem, a ponto de serem quase sufocados pelo fumo proveniente de jacarés (?), alcatrão, e outros combustíveis necessários ao fabrico e conserto das ditas embarcações. Determino, portanto, que, depois da precisa ciência, vir quem possa. ${ }^{23}$
\end{abstract}

Era de se prever que os proprietários dos saveiros e das outras embarcações não aceitariam facilmente a intervenção de terceiros e da Municipalidade no seu ambiente de trabalho. Tanto assim, que em 19 de maio do mesmo ano, encabeçados por Bernardo Joaquim de Faria, recorreram à Câmara Municipal no intuito de resguardar seus direitos. Como os falueiros da praia de D. Manoel ou os possuidores de botes e canoas da ilha das Cobras ${ }^{24}$ - e demonstrando ser praxe nas súplicas junto à instituição camarária - os cinco peticionários fizeram questão de registrar, além da utilidade do seu serviço para o público, a utilidade à Câmara

22 Grifo nosso. AGCRJ. Série Embarcações: Códice 57.3.11 (1813-1903) - Vários documentos acerca do tráfego, pesca e venda de mercadorias: Certidão de inteiro o teor de um requerimento que me foi dirigido pelos moradores em frente do logradouro público que existe entre as ruas do Cemitério e do Propósito, bem como o teor do meu despacho proferido nesse requerimento, p. 52-54; 56-58.

23 AGCRJ. Série Embarcações: Códice 57.3.11 (1813-1903) - Vários documentos acerca do tráfego, pesca e venda de mercadorias, p. 52-54; 56-58.

24 SANTOS JUNIOR. "Sobre as águas da Guanabara", p. 118-150. 
Municipal no que se refere aos "avultados impostos que pagam", ${ }^{25}$ demonstrando estarem dentro da lei no que concerne ao pagamento dos emolumentos municipais e da sua importância para a arrecadação da Municipalidade.

Justificando a presença e o uso do logradouro para a fabricação, conserto e limpeza de suas embarcações, os Suplicantes informaram que a praia da Saúde estava destinada há longos anos para tal fim, constituindo um direito de uso, sem que fossem importunados pelos fiscais das administrações passadas ou da atual, a qual reconheceria o exposto como verdade e o direito ao uso daquele logradouro. Queixavam-se da ocupação das áreas de marinha da Corte, afirmando não existir local público disponível para as suas embarcações e de outros tantos trabalhadores que se utilizavam daquela praia.

Afirmavam terem sido surpreendidos pelo edital do juiz de paz, que fora publicado no $\mathrm{n}^{\circ} 72$ do Diário do Rio de Janeiro, proibindo os Suplicantes de continuarem no uso do local sob a acusação de estarem infringindo as posturas municipais nos itens já indicados. Para Bernardo e os outros Suplicantes, há muito tempo diversas embarcações afluíam naquela praia para os mesmos fins que os deles e sem que "houvesse quem se queixasse desta prática, a não ser insignificante número de pescadores, que pretendem ter de propriedade aquela marinha para as suas canoas, e que para esse fim se acobertam com a capa de zelosos defensores dos direitos do povo". ${ }^{26}$

Em nota marginal ao ofício dos Suplicantes, a Câmara pediu que o juiz de paz informasse sobre o que havia sido exposto na súplica. Em longo ofício, Gabriel Pinto de Almeida esclareceu que há muito tempo vinha ocorrendo desentendimentos entre os moradores e os trabalhadores que atuavam no serviço de descarga dos saveiros e outras embarcações que lá aportavam. E que esses trabalhadores vinham reduzindo os moradores ao desespero com seus consertos e escândalos do qual fora testemunha e que também fora relatado pelo inspetor do distrito que, chegando ao local, os viu se afastarem no mar, em suas embarcações, de onde insultaram o inspetor e os moradores. ${ }^{27}$

O juiz afirmou que agia a partir da representação dos ofendidos moradores da praia da Saúde e que precisava tornar livre o logradouro público das embarcações que atravancavam o embarque e desembarque dos cidadãos que ali recorriam. Indicou no seu ofício que os ditos Suplicantes tinham outras áreas disponíveis no litoral da cidade para fazerem seus consertos, limpeza e fabricação das suas embarcações e que já estavam se utilizando de outra área.

[...] primeiramente a praia que fica ao lado do Cais do Cemitério Inglês, em segundo lugar, a praia que fica entre a casa do pescador João de Muras (?), e a de Joanna Chiyarra (?); em terceiro lugar a Praia da Gamboa, e finalmente em toda extensão na praia de São Cristóvão até a ponta do Caju, sendo certo, que desde a proibição deste juízo os requerentes se servem dos dois primeiros lugares acima apontados, em cujos lugares não havendo moradores, não podem ser estes incomodados, nem correr o perigo de funestos crimes. ${ }^{28}$

25 AGCRJ. Série Embarcações: Códice 57.3.11 (1813-1903) - Vários documentos acerca do tráfego, pesca e venda de mercadorias: Súplica solicitando a continuidade do uso do logradouro situado na praia da Saúde. pp. 50/50v-51.

26 AGCRJ. Série Embarcações: Códice 57.3.11 (1813-1903) - Vários documentos acerca do tráfego, pesca e venda de mercadorias: Ofício solicitando a continuidade do uso do logradouro situado na praia da Saúde. pp. 50/50v-51.

27 AGCRJ. Série Embarcações: Códice 57.3.11 (1813-1903) - Vários documentos acerca do tráfego, pesca e venda de mercadorias: Ofício solicitando a continuidade do uso do logradouro situado na praia da Saúde. pp. 52/52v e 55/55v.

28 AGCRJ. Série Embarcações: Códice 57.3.11 (1813-1903) - Vários documentos acerca do tráfego, pesca e 
Aparentemente, até aí parecia tudo explicado. Gabriel de Pinto Almeida esclareceu suas razões e fundamentou sua decisão, mostrando, inclusive, que os Suplicantes já vinham se utilizando de outra área. Mas a Câmara Municipal ainda queria mais esclarecimentos acerca do imbróglio entre os moradores e os remadores e barqueiros da praia da Saúde. Tanto assim, que em despacho de 9 de junho de 1841, o vereador Ezequiel, crendo no que fora relatado pelo juiz, mas também levando em consideração a súplica de Bernardo e seus colegas, pediu que fosse ouvido o vereador Ferreira, morador antigo da região e que, provavelmente, conheceria tanto os Suplicantes, quanto os moradores do logradouro sob litígio e se as suas alegações eram verdadeiras ou não. O dito vereador foi favorável aos moradores do logradouro situado entre as ruas do Cemitério e do Propósito, em razão das alegações reunidas nos documentos, e deu parecer a favor de que fosse concedida a praia em frente ao Cemitério dos Ingleses para que os Suplicantes pudessem lá encalhar suas embarcações e fazer a limpeza, conserto e fabrico delas. ${ }^{29}$

Conforme podemos verificar na figura 1, a praia da Saúde $(A)$, era mais próxima do Arsenal de Marinha (B) e da Alfândega (D), que ficavam na praia dos Mineiros (C), principal ponto de atracação da cidade. O Cemitério dos Ingleses já estava mais distante, na praia da Gamboa (E), do outro lado do morro da Saúde.

Figura 1

\section{Planta do Rio de Janeiro de 1831}

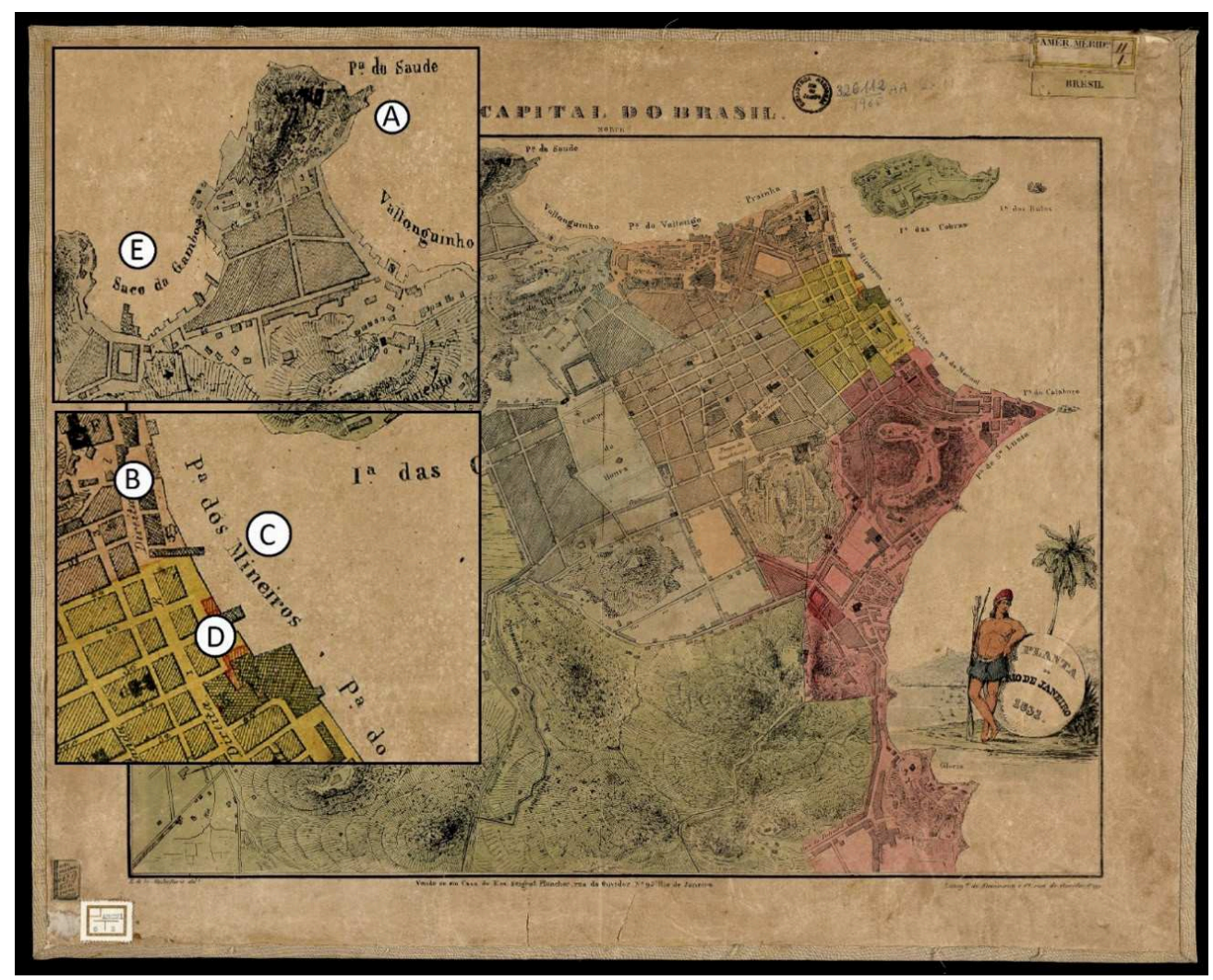

Fonte: Fundação Biblioteca Nacional - BN Digital. ${ }^{30}$

venda de mercadorias: Ofício solicitando a continuidade do uso do logradouro situado na praia da Saúde. pp. 52/52v e 55/55v.

29 AGCRJ. Série Embarcações: Códice 57.3.11 (1813-1903) - Vários documentos acerca do tráfego, pesca e venda de mercadorias: Ofício solicitando a continuidade do uso do logradouro situado na praia da Saúde. pp. 48/48v e 49/49v.

30 MICHELLERIE, E. de La. Planta do Rio de Janeiro. Rio de Janeiro: Lithoga de Steinmann, 1831. 1 planta, litografia, aquarelada, col, 35,8 x 47. Disponível em: http://objdigital.bn.br/acervo_digital/div_cartografia/ cart326112/cart326112.jpg. Acesso em: 13/09/2017. 
Todo o processo termina por ser um pouco longo, diante da troca de ofícios entre as instituições envolvidas no imbróglio e a assertividade dos litigantes nas colocações e na defesa dos seus interesses. Mas é ilustrativo dos instrumentos disponíveis e das estratégias utilizadas pelos cidadãos e trabalhadores durante o século XIX na reivindicação dos seus direitos, assim como na defesa da atuação dos seus ofícios e dos seus espaços de trabalho.

É sintomático que os moradores que se sentiam diariamente incomodados com a presença e atuação dos remadores e barqueiros na praia da Saúde tenham recorrido diretamente ao juiz de paz do Segundo Distrito da freguesia de Santa Rita. É muito provável que esses cidadãos já viessem reclamando da situação que vinha ocorrendo com os fiscais e guardas municipais responsáveis por aquela praia, uma vez que era uma preocupação constante nos relatórios dos funcionários responsáveis pelo controle do cotidiano da cidade a vigilância sobre a força de trabalho espalhada pela cidade. Nesse caso, o trabalho dos fiscais das freguesias estava bem especificado no Código de Posturas de 1838. Residia neles a responsabilidade de exercer o papel de braço do Poder Municipal sobre os cidadãos e trabalhadores da cidade. Na Sessão Segunda, Título $12^{\circ}$ :

$\S 4^{\circ}$ Os fiscais ficam autorizados por em custódia à sua ordem, até satisfação da multa, os infratores de posturas que forem desconhecidos ou escravos; e a mandá-los soltar, quando no artigo violado não haja pena de prisão.

$\S 5^{\circ}$ Os fiscais requisitarão às autoridades civis ou militares todo o auxílio que julgarem preciso para a boa execução das posturas, assim como poderão chamar qualquer cidadão para os coadjuvar em alguma diligência. $O$ cidadão que se negar a esta requisição será multado em $10 \$ 000$ réis, sendo posto em custódia até satisfação da multa. ${ }^{31}$

Os fiscais não andavam sozinhos nas suas tarefas e contavam com o auxílio dos guardas municipais, que estavam subordinados tanto aos fiscais, quanto aos juízes de paz, que constavam do Código de Posturas como mediadores entre os cidadãos e os funcionários municipais, conforme as disposições gerais acerca dos meios de execução..$^{32}$ No que tange aos guardas municipais, "a câmara nomeará para cada freguesia dois ou mais guardas municipais, os quais serão obrigados a obedecer às ordens e chamamento dos fiscais, e rondarão as ruas da sua freguesia, para vigiarem sobre as infracções de posturas." 33

Desde o Código de Posturas de 1830, à Câmara ficava regulado o controle sobre o cotidiano da cidade e a rotina dos seus moradores de maneira institucionalizada. $\mathrm{Na}$ Constituição de 1824 ficou estipulado que caberia às câmaras municipais o controle econômico e social das cidades e vilas da sua jurisdição. ${ }^{34} \mathrm{~A}$ lei de outubro de 1828, que ficou conhecida como Regimento das Câmaras, determinava o funcionamento, atribuições e deveres e determinava que:

[...] estariam submetidas a um poder superior, função que caberia aos presidentes de província, com a exceção da Corte. Esta, por se tratar da sede do Governo, estaria subordinada ao Ministério dos Negócios do Império. O Ato Adicional de 1834 ampliou ainda mais o poder dos órgãos externos sobre as Câmaras..$^{35}$

31 Código de Posturas da llustríssima Câmara Municipal do Rio de Janeiro e Editais da mesma Câmara, 1838.

32 Código de Posturas da Ilustríssima Câmara Municipal do Rio de Janeiro, 1830.

33 Parágrafos $1^{\circ}$ e $2^{\circ}$, Seção $2^{\mathrm{a}}$, Título $12^{\circ}$. Código de Posturas da llustríssima Câmara Municipal do Rio de Janeiro e Editais da mesma Câmara, 1838.

34 TERRA. Cidadania e trabalhadores, p. 129.

35 TERRA. Cidadania e trabalhadores, p. 130. 
Com essa lei, aliada ao Ato Adicional de 1834, as sanções às medidas tomadas pela instituição camarária tornaram seu espaço de manobra e autonomia criticamente estreito. Umas das figuras que contribuíram para a sobreposição de jurisdição na observação e controle das posturas municipais foi o Juízo de Paz. O Código de 1830 já previa a intermediação deles no controle sobre a rotina dos cidadãos. Não se poderia mais sepultar um corpo sem a participação do juiz de paz da freguesia, tomando ciência do local e apresentando certidão para tanto. ${ }^{36}$ Assim como foi determinado o destino dos embriagados, que deveriam ser a ele encaminhados ${ }^{37}$ ou, ainda, fornecer as informações necessárias aos moradores que possuíssem poços de água em suas casas que estivessem próximas de incêndios. ${ }^{38}$

Portanto, os funcionários da municipalidade já deveriam estar cientes dos imbróglios que vinham ocorrendo e nada produziram para resolver a situação. Logo, ao buscar na figura do juiz leigo a intermediação na reivindicação das suas demandas, eles demonstraram que havia o domínio da legislação em vigor, principalmente no que concerne ao Código de Processo Criminal e das atribuições do cargo enquanto força conciliatória e de fiscalizador das posturas municipais. Em sua representação, os moradores destacaram o papel do juiz de paz de "fiscal" das posturas, com poder de execução das penalidades previstas na legislação municipal em vigor. Assim, reconheciam as múltiplas ferramentas disponíveis na luta diária pelo exercício da cidadania e na defesa dos seus diretos.

Por outro lado, o acionamento da Câmara Municipal pelos proprietários de saveiros e outras embarcações também diz muito da relação dessas personagens com a instituição camarária e da função dela como reguladora e controladora do mundo do trabalho. Eles recorreram à municipalidade para decidir sobre a inibição do uso da praia, que ocupavam há longos anos sem serem importunados pelos ficais da freguesia - de antes ou da atual administração. Passou-se, aproximadamente, pouco mais de um mês entre a publicação do edital e a súplica de Bernardo Joaquim de Faria e seus colegas (o edital foi publicado em $1^{\circ}$ de abril e a representação dos proprietários é de 19 de maio). Muitos fatores podem ter contribuído para esperarem esse tempo transcorrer até que tomassem a iniciativa, mas muito mais provável é que tenham percebido que o lugar não provia os mesmos ganhos que a atuação na praia da Saúde proporcionava. Como o juiz de paz explicou, a praia em frente ao Cemitério dos Ingleses era desprovida de população e, mais importante, enquanto embarcações de descarga, estavam ainda mais distantes do centro da cidade do que estavam na praia anterior, que era melhor localizada se pensarmos na proximidade do logradouro com a praia dos Mineiros ou do Cais Pharroux, conforme se vê na figura 1.

É provável que não utilizassem suas embarcações somente para o transporte de mercadorias, mas também de passageiros e a praia da Saúde era muito favorável a esse tipo de serviço, uma vez que estava próximo do Cais da Imperatriz (Valongo) e ficava na rota do itinerário entre São Cristóvão e o Cais dos Mineiros. Além disso, os remadores que atuavam diariamente nas embarcações já tinham sua rede de sociabilidade estabelecida naquele logradouro, onde atuariam em outras atividades paralelamente ao serviço de carga, descarga e na manutenção dos ditos saveiros.

36 Seção Primeira, Título Um, §5 . Código de Posturas da llustríssima Câmara Municipal do Rio de Janeiro, 1830.

37 Seção Segunda, Título Terceiro, $\S 6^{\circ}$. Código de Posturas da Ilustríssima Câmara Municipal do Rio de Janeiro, 1830.

38 Seção Segunda, Título Sétimo, §17. Código de Posturas da llustríssima Câmara Municipal do Rio de Janeiro, 1830. 
O pagamento de impostos era um fato destacado nas representações de negociantes, comerciantes e trabalhadores junto à Câmara Municipal, como fizeram Bernardo Joaquim de Faria e seus colegas. Ele era possuidor de 15 saveiros de descarga 39 e, junto com os outros Suplicantes, deveriam julgar que tinham precedência no uso do lugar, por terem mais embarcações e seus impostos serem mais avultados do que dos barqueiros que acusava.

A despeito do que determinava as posturas municipais, os proprietários de saveiros e outras embarcações de descarga acreditavam que não as estavam infringindo, por ali atuarem há longos anos, por considerarem de utilidade pública o seu serviço e, principalmente, por estarem quites com o pagamento dos impostos, e acionavam a instituição camarária para garantir o espaço que usavam por direito adquirido. Os moradores do logradouro entre as ruas do Cemitério e do Propósito, por sua vez, buscaram outras instâncias para lutarem por espaços de trabalho, para atenuarem a fragilidade das suas condições sociais e para conseguirem melhores proventos dos seus ofícios.

O reconhecimento da figura do juiz de paz em contraposição à Municipalidade demonstra que os cidadãos e trabalhadores do Rio de Janeiro da primeira metade do século XIX entendiam as funções e a importância da figura do juiz de paz no cotidiano da cidade. A revisão do Código de Processo Criminal, sob a Lei $n^{\circ} 261$, de 3/12/1841, veio garantir em lei as restrições ao extenso poder dessas personagens e constranger uma estratégia que vinha sendo utilizada há muito tempo pela população da Corte nas suas reivindicações. Segundo Juliana Teixeira de Souza, "até a década de 1840, competia apenas aos fiscais de freguesia e aos guardas municipais fiscalizar o cumprimento das posturas municipais"..$^{40}$ Entretanto, desde a criação do Juízo de Paz, em 1827, o papel de fiscalizador das posturas policiais da Câmara, com força para impor as penalidades previstas, já estava marcado e os moradores do logradouro público sob disputa mostraram que os cidadãos conheciam e acionavam esse dispositivo nas suas estratégias de luta desde que o cargo fora criado.

\section{O juizado leigo: um fator de concorrência com a Câmara Municipal}

O cargo de juiz de paz foi estabelecido em 1827, mas já estava previsto desde a promulgação da Constituição de 1824 . O cargo era eletivo pela mesma maneira e tempo que os vereadores da cidade e todos aqueles que fossem eleitores poderiam se candidatar ao cargo criado. ${ }^{41}$ Dentre as atribuições do juiz, estavam a de conciliar as partes em atrito e mediá-las, julgando pequenas demandas "cujo valor não exceda a $16 \$ 000$, ouvindo as partes, e a vista das provas apresentadas por elas", assim como "fazer observar posturas policiais das Câmaras, impondo as penas delas aos seus violadores". ${ }^{42}$ Havia dezesseis juízes de paz na cidade: dois nas freguesias de Santa Rita, Candelária, São José, Glória, Sant’Anna e Engenho

39 SANTOS JÚNIOR. "Sobre as águas da Guanabara", p. 158.

40 SOUZA. "A autoridade municipal na Corte imperial", p. 20.

41 BRASIL. Lei de 15 de outubro de 1827, art. $2^{\circ}$ e $3^{\circ}$. Disponível em: http://www.planalto.gov.br/ccivil_03/leis/ LIM/LIM-15-10-1827.htm. Acessado em: 13/09/2017.

42 BRASIL. Lei de 15 de outubro de 1827 , art. $2^{\circ}$ e $3^{\circ}$. Disponível em: http://www.planalto.gov.br/ccivil_03/leis/ LIM/LIM-15-10-1827.htm. Acessado em: 13/09/2017. 
Velho; três na freguesia de Sacramento e um no distrito da Lagoa. ${ }^{43}$ Na década de 1840, mais precisamente em dezembro de 1841, o Código de Processo Criminal foi revisado e ampliado, incluindo a Secretaria de Polícia na observação dos assuntos que diziam respeito às posturas municipais, inclusive a regulação dos mercados e diversas outras atividades econômicas da cidade. ${ }^{44}$ Originalmente, o cargo de juiz leigo foi criado com força conciliatória e agindo em ações que não alcançassem valores muito altos. ${ }^{45}$

Segundo Thomas Flory, havia a preocupação filosófica e ideológica dos políticos liberais dos anos 1820 de democratizar o acesso à estrutura legal, contrapondo-se à herança colonial de exclusivismo judicial e ao que se considerava à época, um esforço dos juízes profissionais, formados na Universidade de Coimbra, de fazer do conhecimento e do acesso à lei um item inacessível aos não letrados ou iniciados nos assuntos legais. Os juízes de paz teriam sido uma forma eficaz encontrada por esses políticos de lograr tal intento, posto que foram eleitos localmente e conheciam as demandas regionais. ${ }^{46}$

O cargo teria atendido a um interesse liberal de desafiar a autoridade do imperador como árbitro final e supremo do Judiciário brasileiro. ${ }^{47}$ Assim, os juízes de paz funcionariam como uma forma de legislar localmente, esvaziando o poder central e servindo de apoio político liberal nas freguesias. ${ }^{48} \mathrm{~A}$ criação do cargo também contribuiria para o processo de tentativa de esvaziamento das Câmaras Municipais, ao retirar delas a nomeação dos cargos de juiz ordinário, de vintena ou o almotacel, extintos com a chegada dos juízes de paz. ${ }^{49}$

O surgimento da figura do juiz de paz girou em torno de dois argumentos, segundo Ivan Vellasco: o primeiro refere-se à estrutura jurídica herdada do período colonial, na qual predominaria os magistrados profissionais e seus sistemas de emolumentos; o segundo se refere à horizontalização da Justiça, fundada no sistema constitucional, formando a base da construção do Estado. ${ }^{50}$

O conflito entre a estrutura preexistente e esse novo personagem posto em cena seria agravado pelos amplos poderes nele investidos, em desafio a prerrogativas estabelecidas e acusando a ineficácia de uma ordem jurídica, à frente da qual se postavam os magistrados, com suas distinções meritocráticas, obtidas pela formação em Coimbra. ${ }^{51}$

No que concerne à pesquisa nas regiões de Minas Gerais propostas por Vellasco, a introdução do juiz de paz na resolução das demandas proporcionou o aumento da atividade judiciária, em contraposição a um período colonial no qual a marca dos serviços jurídicos era a morosidade. Esse processo seria explicado por um período inicial caracterizado pela cooperação entre esses juízes recém ingressos, ainda testando os limites das suas atribuições e o respeito pela preeminência da sua

43 HOLLOWAY, Thomas H. Polícia no Rio de Janeiro: repressão e resistência numa cidade do século XIX. Tradução: Francisco de Castro Azevedo. Rio de Janeiro: Ed. Fundação Getúlio Vargas, 1997, p. 112.

44 SOUZA, Juliana Teixeira. "As Câmaras Municipais e os trabalhadores no Brasil Império". Revista Mundos do Trabalho, Santa Catarina, vol. 5, n 9, p. 11-30, 2013, p. 20.

45 FLORY, Thomas. El juez de paz y el jurado en el Brasil Imperial, 1808-1871: control social y estabilidad política en el nuevo Estado. México: Fondo de Culture Económica, 1986, p. 81

46 FLORY. El juez de paz y el jurado en el Brasil Imperial, p. 95.

47 FLORY. El juez de paz y el jurado en el Brasil Imperial, p. 84.

48 FLORY. El juez de paz y el jurado en el Brasil Imperial, p. 85.

49 FLORY. El juez de paz y el jurado en el Brasil Imperial, p. 90.

50 VELLASCO, Ivan de A. "O juiz de paz e o código do processo: vicissitudes da justiça imperial em uma comarca de Minas Gerais no século XIX”. Justiça \& História, Rio Grande do Sul, v. 3, n. 6, p. 65-96, 2003. p. 5.

51 VELLASCO. "O juiz de paz e o código do processo", p. 6. 
posição na região. Outra explicação residiria num cenário no qual a competição entre os juízes de paz e os juízes letrados disputariam a excelência do exercício da prática judicial, buscando o apoio e o reconhecimento tanto da elite política local, quanto da população mais pobre, que reconheceria na nova instituição uma autoridade local a quem pudessem recorrer. ${ }^{52}$

[...] é razoável supor que os homens que inicialmente se dispuseram a exercer o posto, experimentaram o sentido de compromisso e o peso moral que emanava da investidura de um cargo respaldado publicamente e no qual eram depositadas as mais entusiásticas expectativas de mudança e progresso. ${ }^{53}$

De acordo com Thomas Holloway, o fato dos cidadãos da cidade elegerem o juiz de paz legitimava a sua autoridade, que emanava da sua vontade e não do Imperador, "representando a primeira ruptura clara com o conceito de autoridade judicial emanada do monarca, o juiz de paz tinha o potencial para tornar-se um divisor de águas na maneira de exercer o poder e regulamentar a sociedade". ${ }^{54}$

Flory acredita que, por ser eleito, essa figura se imiscuía às relações políticas e sociais da freguesia em que atuava e as suas decisões deveriam atender a tais interesses. $O$ autor explica que os juízes eleitos deviam seus cargos a algumas das muitas partes contendentes que chegavam até ele, comprometendo a imparcialidade inerente ao cargo de conciliador. Por terem cargos temporários, não se sentiriam obrigados a se indispor com muitos dos seus vizinhos e colegas ${ }^{55}$. Para Flory, a conciliação era um dever e não um poder do juiz de paz:

Como não havia sanção, os alegados litigantes sempre podiam se recusar a conciliar. [...] Em quase todos os casos trazidos diante dele, uma tentativa ativa do magistrado para se conciliar provavelmente o levaria a um inimigo desnecessário. Se ele fizesse muitas conciliações, certamente o colocaria em mau estado com os membros do tribunal local, que ganhavam a vida sangrando os litigantes. Assim, a solução encontrada pela maioria dos magistrados provavelmente foi passiva. ${ }^{66}$

O excesso de atribuições e de poder concedido a essa figura leiga e as suspeitas de estar sujeito às influências dos poderes locais foram as críticas mais fortes sofridas pelo Juízo de Paz desde o Ato Adicional de 1834. Adiciona-se a essas questões a independência do cargo frente à magistratura profissional, causando forte desconforto e mais críticas nos magistrados daqueles anos. ${ }^{57}$ No entanto, residiria no alto número de absolvições contra um baixo número de condenações o maior problema a ser atacado. Para Adriana Campos, o movimento de revisão das reformas liberais dos primeiros anos 1830 liderado pelos políticos conservadores, refletiria mais uma dificuldade própria de enfrentar um cenário

52 VELLASCO. "O juiz de paz e o código do processo", p. 10.

53 VELLASCO. "O juiz de paz e o código do processo", p. 12.

54 HOLLOWAY. Polícia no Rio de Janeiro, p. 61.

55 FLORY. El juez de paz y el jurado en el Brasil Imperial, p. 100.

56 "Como no había una sanción, los presuntos litigantes siempre podían negarse a ser conciliados. [... ] En casi cualquier caso que se traía ante él, un intento activo del magistrado por conciliar probablemente le acarrearía un enemigo innecesario. Si realizaba demasiadas conciliaciones, eso ciertamente lo pondría en malos términos con los miembros del juzgado local, que se ganaban la vida desangrando a los litigantes. Así, la solución que encontró la mayoría de los magistrados probablemente fue pasiva". FLORY. El juez de paz y el jurado en el Brasil Imperial, p. 100.

57 CAMPOS, A. P. "Juízes de fato: participação e administração da justiça local”. Dimensões: Revista de História da UFES, v. 28, p. 103-122, 2012, p. 109. 
burocrático sem hierarquizações e menos uma possível falta de eficiência do Tribunal de Júri ou dos juízes de paz..$^{58}$ Dessa forma, "o problema da ordem recaía sobre os juízes de paz eletivos e o júri, juízes municipais, de órfãos e promotores eleitos". 59

No entanto, a crítica ao juizado leigo reunia liberais e conservadores na busca de uma revisão que tratasse essa questão de modo a reequilibrar o poder político provincial e imperial. A partir de 1837, com a organização do Partido Conservador, a pressão por mudanças no Código de Processo Criminal intensificou-se e congregou liberais insatisfeitos com o papel do juiz de paz nos arranjos políticos locais e que, desde os primeiros debates sobre o Código de Processo Criminal de 1832, se colocavam contra a magistratura eleita. ${ }^{60}$ Para Miriam Dolhnikoff, o cerne da revisão conservadora de 1841 residiu na reforma do Judiciário, para que o controle dessas autoridades pudesse ser centralizado. Nesse sentido, líderes liberais como Manuel Alves Branco e Feijó colocaram-se a favor de mudanças tanto no Código quanto no Ato Adicional que permitissem esse controle. ${ }^{61}$

\begin{abstract}
A revisão conservadora tinha conteúdo diverso do que propunha a oposição derrotada em 1832 e 1837. O que movia os conservadores era a constatação de que as reformas liberais haviam falhado no que dizia respeito à organização judiciária. Em nome do combate ao caos e à anarquia o que propugnavam era retirar das Assembleias Provinciais o direito de intervir na magistratura e limitar o poder dos juízes de paz, transferindo suas atribuições para funcionários nomeados pelo governo central. ${ }^{62}$
\end{abstract}

Por não atacar o pacto federativo conquistado em 1834, a convergência entre liberais e conservadores nesse ponto mostrou que as disputas políticas giravam em torno de pontos específicos e se relacionava menos com divergências entre projetos políticos. ${ }^{63} \mathrm{~A}$ figura do juiz de paz e o acúmulo de poderes e experiência na atuação de conciliação e outras atividades de polícia e julgamento ofereceu um ambiente de participação popular e um espaço de reivindicação de direitos que desagradou uma elite política ciosa do controle social.

Como vimos, o juiz de paz do Segundo Distrito da freguesia de Santa Rita foi assertivo e diligente com relação à reclamação dos moradores da praia da Saúde. No mesmo dia mandou publicar o edital que atendia às solicitações dos reclamantes, acatando todos os seus pedidos em prejuízo de comerciantes, incluindo um barão, estabelecidos em uma área nobre da cidade e com claros interesses na região. É importante destacar que tratamos da capital do Império e a atuação dos juízes de paz não foi a mesma nas diversas regiões que contavam com a presença de um deles. O próprio Flory registra que nas freguesias rurais e urbanas essa figura agiu de formas diferentes, mesmo pela própria rede relação a que eles pertenciam. ${ }^{64}$

Entre as suas muitas funções, ao juiz de paz também estava encarregada a observância e fiscalização dos contratos de locação de serviços estabelecidos pelas leis de 1830 e $1837^{65}$ que definia direitos e deveres dos trabalhadores

58 CAMPOS. “Juízes de fato", p. 113.

59 CAMPOS. "Juízes de fato", p. 112.

60 DOLHNIKOFF, Miriam. O pacto imperial: origens do federalismo no Brasil do século XIX. São Paulo: Globo, 2005, p. 127.

61 DOLHNIKOFF. O pacto imperial, p. 128-129.

62 DOLHNIKOFF. O pacto imperial, p. 130.

63 DOLHNIKOFF. O pacto imperial, p. 131.

64 DOLHNIKOFF. O pacto imperial, p. 98.

65 Ver: Lei de 13 de setembro de 1830. Disponível em: http://www2.camara.leg.br/legin/fed/lei_sn/1824- 
estrangeiros não africanos no Brasil. Com relação aos escravizados, os juízes de paz tinham que estar cientes e mandar destruir os quilombos, impedindo, inclusive, a sua formação. Com a lei de 1831, de cessação do tráfico negreiro, passaram a ter a competência de "visitar os barcos que dessem entrada ou saída aos portos, verificando a regularidade quanto ao cumprimento da lei eautorizando o desembarque ou seu despacho". ${ }^{66}$ Dessa maneira, é perceptível como a figura do juiz de paz estava ligada diretamente ao controle, fiscalização e normalização das questões relacionadas ao mundo do trabalho e ajuda a compreender por que os moradores e trabalhadores da praia da Saúde recorreram ao juiz de paz para resguardar seus direitos frente aos constrangimentos que vinham sofrendo há muito tempo.

Analisando a atuação do juiz de paz do município de Campinas em 1865, Joseli Mendonça demonstrou que, ao contrário do que afirma Flory, as decisões dos juízes de paz nem sempre acompanharam os interesses dos grupos hegemônicos dominantes ou da elite da região, mas "a ação dos juízes de paz estava em estreita conexão com questões cruciais referentes ao controle dos trabalhadores e, nesse sentido, com as experiências sociais dos sujeitos aos quais ela se referia". ${ }^{67}$ Mesmo para um período posterior ao nosso e resguardadas as mudanças nas atribuições dos juízes de paz na segunda metade do século XIX, o caso apresentado por Mendonça ajuda a ilustrar como os trabalhadores oitocentistas tiveram à mão diversos instrumentos na defesa dos espaços de trabalho e de resistência ao controle político sobre seus ofícios. A legislação referente às atribuições do cargo variou e alargou-se bastante até a reforma do Código de Processo Criminal e ainda aguardamos pesquisas que aprofundem a atuação do juizado leigo nas relações de trabalho na cidade do Rio de Janeiro.

\section{Considerações finais}

Como vimos, o processo político da década de 1840 foi profícuo de mudanças nas estruturas centrais, locais e no cotidiano dos cidadãos do Império e, no caso, do Rio de Janeiro. Desde o processo de emancipação política, a população se viu diante de novas formas de interação com as instituições e de reivindicação de direitos, contribuindo para uma maior participação na vida da cidade. Ao longo da primeira metade do XIX, os cidadãos foram tomando conta do espaço político através do instrumento peticionário, que se horizontalizou como estratégia na luta diária por melhores condições de vida e de trabalho.

O contexto da virada conservadora verificada nessa década buscou retirar dos poderes locais muitas atribuições que diziam respeito ao controle sobre os espaços de trabalho no Império. A revisão do Código de Processo Criminal realizada em 1841, com a criação das delegacias e subdelegacias subordinadas diretamente ao Ministério da Justiça significou a centralização do processo criminal e, consequentemente, da autoridade sobre os cidadãos e os trabalhadores das cidades brasileiras no que tange às suas reivindicações e disputas cotidianas.

1899/lei-37984-13-setembro-1830-565648-publicacaooriginal-89398-pl.html. Acessado em: 31/08/2015; Lei de 11 de outubro de 1837. Disponível em: http://legis.senado.gov.br/legislacao/ListaTextolntegral. action?id=62158\&norma=78042. Acessado em: 31/08/2015.

66 MENDONÇA, Joseli Maria Nunes. "Os juízes de paz e o mercado de trabalho Brasil, século XIX". In: RIBEIRO, G. S.; NEVES, E. A.; FERREIRA, Maria de Fátima Cunha Moura. (Org.). Diálogos entre Direito e História: cidadania e justiça. Niterói: EdUFF, 2009, p. 240-241.

67 MENDONÇA. "Os juízes de paz e o mercado de trabalho Brasil”, p. 252. 
Nesse sentido, os espaços de trabalho - o mundo do trabalho em si - ficaram sob responsabilidade das autoridades do governo imperial.

Tal centralização judiciária foi endereçada, principalmente, para o controle sobre a magistratura leiga, como defendem os analistas de história política. No entanto, até o momento tem sido desconsiderado o fator social nas mudanças políticas ao longo do Império brasileiro. Como foi mostrado neste artigo, a participação através das petições foi um recurso usado largamente em diferentes situações e por diversos motivos. No caso dos moradores da praia da Saúde, as disputas de poder provocadas pelas sobreposições de jurisdição entre a Municipalidade e o juizado leigo abriram espaços para estratégias importantes na disputa pelos espaços de trabalho da cidade.

Dessa forma, reduzir o poder dos juízes de paz e das Câmaras Municipais, além de ter sido uma forma de diminuir o tamanho político dessas instituições, mais ou tão importante quanto, foi reduzir a importância delas e o que elas significavam para os cidadãos como ferramentas nas suas estratégias de lutas por direitos. As ações dos trabalhadores ao acionar constantemente as autoridades locais para resguardarem seus direitos foi um fator que contribuiu decididamente para a percepção do excesso de poder que residia nelas, bem como a concorrência entre as autoridades locais.

Isto posto, o que este artigo se propôs a mostrar é que a luta por direitos diversos na cidade do Rio de Janeiro estava intrinsicamente ligada às questões do mundo do trabalho. Uma luta que é política em todas suas dimensões. A vitória dos moradores da praia da Saúde sobre um grupo de comerciantes da praça do comércio da Corte é simbólica e sintomática. É um símbolo do que representava a figura do juiz de paz - a das autoridades locais - para os cidadãos da cidade e o seu papel de fiscalizador das posturas municipais, podendo ser um instrumento valioso contra interesses econômicos dominantes. É sintomático da importância da participação política pelos meios institucionais entre os trabalhadores da cidade que, através das petições e dos requerimentos, acionavam diferentes instâncias para resguardar os seus interesses e os seus espaços de trabalho. Ao se utilizarem das sobreposições de jurisdição entre as instituições locais, os trabalhadores da cidade conseguiram vitórias importantes para a garantia dos seus espaços de trabalho, por condições de vida mais dignas e, assim, contribuíram para a construção de uma cidadania oitocentista que entrelaçava diferentes formas de ação política. 
